\title{
Can nitrocobalamin be reduced by ascorbic acid to nitroxylcobalamin? Some surprising mechanistic findings
}

\author{
Justyna Polaczek ${ }^{1} \cdot$ Łukasz Orzeł $^{1} \cdot$ Grażyna Stochel $^{1} \cdot$ Rudi van Eldik $^{1,2}$
}

Received: 7 December 2017 / Accepted: 1 February 2018 / Published online: 12 February 2018

(C) The Author(s) 2018. This article is an open access publication

\begin{abstract}
Despite detailed studies on nitroxylcobalamin (CblNO) formation, the possible intracellular generation of CblNO via reduction of nitrocobalamin $\left(\mathrm{CblNO}_{2}\right)$ remains questionable. To study this further, spectroscopic studies on the reaction of $\mathrm{CblNO}_{2}$ with the intracellular antioxidant ascorbic acid $\left(\mathrm{HAsc}^{-}\right)$were performed in aqueous solution at $\mathrm{pH}<5.0$. It was found that nitroxylcobalamin is the final product of this interaction, which is not just a simple reaction but a rather complex chemical process. We clearly show that an excess of nitrite suppresses the formation of CblNO, from which it follows that ascorbic acid cannot reduce coordinated nitrite. We propose that under the influence of ascorbic acid, nitrocobalamin is reduced to $\mathrm{Cbl}(\mathrm{II})$ and nitric oxide ( $\mathrm{NO}$ ), which can subsequently react rapidly to form CblNO. It was further shown that this system requires anaerobic conditions as a result of the rapid oxidation of both $\mathrm{Cbl}(\mathrm{II})$ and CblNO.
\end{abstract}

\section{Graphical Abstract}

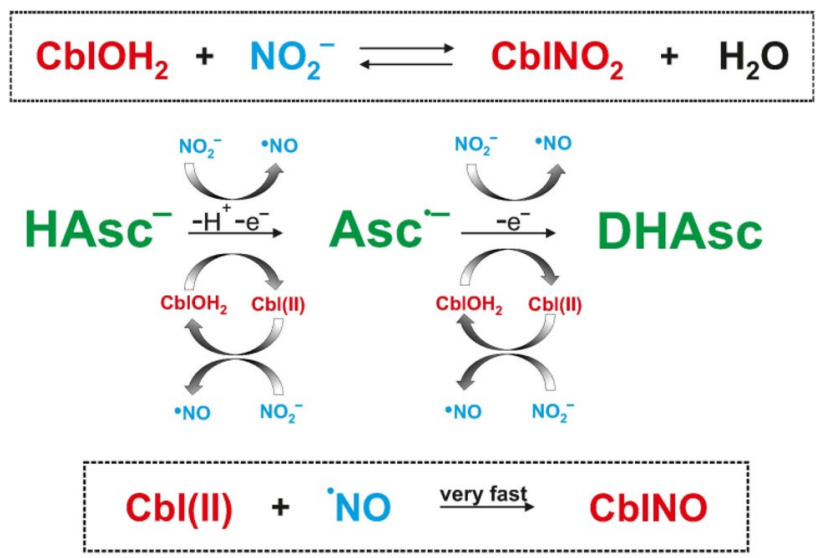

Keywords Nitrocobalamin $\cdot$ Nitroxylcobalamin $\cdot$ Nitrite $\cdot$ Ascorbic acid $\cdot$ Redox reactions

Electronic supplementary material The online version of this article (https://doi.org/10.1007/s00775-018-1540-1) contains supplementary material, which is available to authorized users.

Rudi van Eldik

rudi.vaneldik@fau.de

1 Faculty of Chemistry, Jagiellonian University, Gronostajowa 2, 30-387 Kraków, Poland

2 Department of Chemistry and Pharmacy, University of Erlangen-Nuremberg, Egerlandstrasse 1, 91058 Erlangen, Germany

\section{Introduction}

Nitroxylcobalamin (CblNO, formally $\mathrm{Co}^{\mathrm{III}-\mathrm{NO}^{-}}$) [1] is one of the most interesting forms of Vitamin $\mathrm{B}_{12}$ that was shown to be stable in biological systems $[2,3]$. Under physiological conditions, CblNO can be produced in a very efficient reaction between the major intracellular form of Vitamin $\mathrm{B}_{12 \mathrm{r}}$, viz. cob(II)alamin [4], and nitric oxide ( $\mathrm{NO}$ ) for which $k=7.4 \times 10^{8} \mathrm{M}^{-1} \mathrm{~s}^{-1}$ and $K_{\mathrm{NO}} \approx 1 \times 10^{8} \mathrm{M}^{-1}$ at $25{ }^{\circ} \mathrm{C}$ [5-7]. It has been postulated that cobalamins show 
the potential to eliminate excess $\mathrm{NO}$ from organisms $[8,9]$ since the $\mathrm{Co}^{\mathrm{III}}-\mathrm{NO}^{-}$complex can be protonated at neutral $\mathrm{pH}$ to form $\mathrm{Co}^{\mathrm{III}}-\mathrm{NOH}$, which in turn can undergo aquation to release $\mathrm{HNO}$. The latter species is known to dimerize and decompose to water and gaseous $\mathrm{N}_{2} \mathrm{O}$ in aqueous solution [10].

CblNO is extremely air sensitive $[6,11,12]$ and in the presence of oxygen it rapidly oxidizes to nitrocobalamin $\left(\mathrm{CblNO}_{2}\right)[6,11-13]$. However, the oxidation of CblNO is not just a simple reaction [14]. According to Brasch et al., the mechanism of CblNO oxidation under certain conditions is rather complex, with multiple products that can be formed [15]. Oxidation of CblNO is a reversible process in which $\mathrm{CblNO}_{2}$ can be reduced by strong reducing agents to reform CblNO. Brasch et al. studied the reaction between $\mathrm{CblNO}_{2}$ and one of the strongest intracellular antioxidants glutathione (GSH), as one of the possibilities to form CblNO [16]. An important conclusion from this work is that for a $\mathrm{pH}$ between 4 and 7, reduction of $\mathrm{CblNO}_{2}$ to $\mathrm{CblNO}$ was not observed! Furthermore, the main product of this reaction is glutathionylcobalamin (CblGS). The reported kinetic data suggest that the observed reaction is a two-step process which involves aquacobalamin $\left(\mathrm{CblOH}_{2}\right)$ as an intermediate that rapidly reacts with GSH to form CblGS (Scheme 1) [16].

Our recent study [17] showed that at neutral $\mathrm{pH}(\mathrm{pH} 7.2$, $0.1 \mathrm{M}$ Tris buffer, $25^{\circ} \mathrm{C}$ ), $\mathrm{CblNO}_{2}$ can react with another biological reducing agent, ascorbic acid $\left(\mathrm{HAsc}^{-}\right)$, to form reduced cobalamin (Cbl(II)) as product, but not CblNO as was hoped. Kinetic data showed that both $\mathrm{CblNO}_{2}$ and $\mathrm{CblOH}_{2}$ present in an equilibrium mixture react with $\mathrm{HAsc}^{-}$, but $\mathrm{CblOH}_{2}$ reacts ca. two orders of magnitude faster than $\mathrm{CblNO}_{2}$ (Scheme 2), i.e. $k_{2} \gg k_{3}$. Thus, on addition of ascorbic acid to the equilibrium mixture of $\mathrm{CblOH}_{2}$ and $\mathrm{CblNO}_{2}$, it reacts rapidly with $\mathrm{CblOH}_{2}$ which in turn is reformed through the aquation of $\mathrm{CblNO}_{2}\left(k_{1}=1.4 \times 10^{-2} \mathrm{~s}^{-1}\right.$ at $25{ }^{\circ} \mathrm{C}$ ) and so represents the major reactive species in solution. Furthermore, in the presence of a large excess of nitrite the reduction of $\mathrm{CblOH}_{2}$ can be drastically inhibited due to the formation of $\mathrm{CblNO}_{2}$ [17]. Recent work in our laboratories indicated that this system shows a more interesting behavior under slightly different experimental conditions.

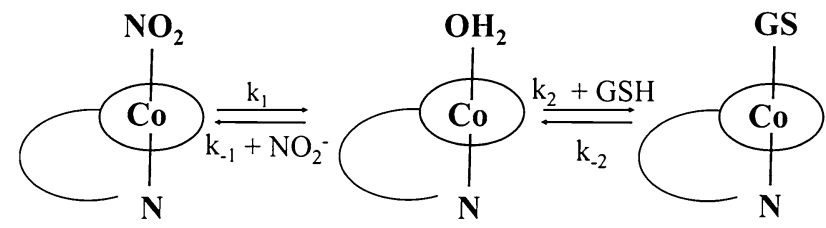

Scheme 1 Schematic presentation of the reaction between $\mathrm{CblNO}_{2}$ and GSH

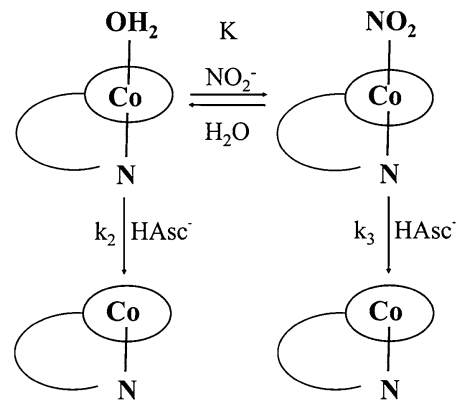

Scheme 2 Suggested mechanism for the reaction between $\mathrm{CblNO}_{2}$ and $\mathrm{HAsc}^{-}$at $\mathrm{pH} \sim 7$

\section{Experimental section}

\section{Materials}

Hydroxocobalamin hydrochloride ( $\mathrm{HOCbl} \cdot \mathrm{HCl}, \geq 98 \%$ ) was purchased from Sigma-Aldrich, sodium nitrite was purchased from LPPH and ascorbic acid was obtained from Polfa Kraków. Acetic acid $\left(\mathrm{CH}_{3} \mathrm{COOH}, \geq 99.5-99.9 \%\right)$ and sodium hydroxide $(\mathrm{NaOH}, \geq 98.8 \%)$ were obtained from a range of suppliers (Sigma-Aldrich, Merck, Fisher Scientific or POCH). All chemicals used throughout this study were of analytical grade or better.

\section{General methods}

All solutions were prepared in de-ionized water using a water purification system. Strictly anaerobic solutions were prepared using appropriate air-free techniques and handling the solutions in appropriate glassware. Oxygen-free argon or nitrogen was used to deoxygenate the reactant solutions. UV-Vis spectral measurements were carried out in screw-cap cuvettes equipped with a silicone septum. $\mathrm{pH}$ measurements were carried out at room temperature using a HI 221 (Hanna Instruments) $\mathrm{pH}$-meter equipped with an AmpHel glass electrode filled with a $3 \mathrm{M} \mathrm{KCl}$ solution.

\section{UV-Vis spectroscopy}

UV-Vis spectra and kinetic data were recorded on Perkin Elmer Lambda 25 spectrophotometer equipped with a thermostated $\left(25.0 \pm 0.1^{\circ} \mathrm{C}\right)$ cell holder (Perkin Elmer PTP-6 Peltier System). All data were analyzed using Origin Lab software. 


\section{Results and discussion}

After completion of our studies at $\mathrm{pH} \sim 7$, we decided to check the influence of ascorbic acid on the reaction with $\mathrm{CblNO}_{2}$ at a more acidic $\mathrm{pH} \leq 5$, where ascorbic acid is mainly present in the mono-protonated form $\mathrm{HAsc}^{-}$and the much weaker reducing agent $\mathrm{H}_{2} \mathrm{Asc}$, depending on the selected $\mathrm{pH}\left(\mathrm{p} K_{\mathrm{a} 1}=4.1\right.$ and $\mathrm{p} K_{\mathrm{a} 2}=11.3$ [18]). Under these conditions, mixtures of $\mathrm{H}_{2} \mathrm{Asc}$ and $\mathrm{HAsc}^{-}$have significantly weaker reducing properties than at $\mathrm{pH} \sim 7$, where ascorbic acid is mainly present as $\mathrm{HAsc}^{-}$with traces of the stronger reducing agent $\mathrm{Asc}^{2-}$ [18-23]. UV-Vis spectra recorded during the reaction between $\mathrm{CblNO}_{2}$ and $\mathrm{HAsc}^{-}$at $\mathrm{pH}<5$ (0.1 M acetate buffer, $25^{\circ} \mathrm{C}$, Ar atmosphere) indicated that $\mathrm{CblNO}_{2}\left(\lambda_{\max }=354,413\right.$ and $\left.532 \mathrm{~nm}\right)$ is not converted to $\mathrm{Cbl(II)}$ as before [17], but appears to be converted directly to nitoxylcobalamin, $\operatorname{CblNO}\left(\lambda_{\max }=316,344\right.$ and $\left.475 \mathrm{~nm}\right)$ [6] with isosbestic points at 335, 373, $490 \mathrm{~nm}$ (Fig. 1a). Under conditions of $\mathrm{pH} 4.3\left(0.1 \mathrm{M}\right.$ acetate buffer, $25^{\circ} \mathrm{C}$, Ar atmosphere), $\left[\mathrm{CblNO}_{2}\right]=8.6 \times 10^{-5} \mathrm{M}$ (obtained by mixing $\mathrm{CblOH}_{2}$ and $\left.\mathrm{NO}_{2}^{-},\left[\mathrm{NO}_{2}^{-}\right] /\left[\mathrm{CblOH}_{2}\right]=5\right)$ and $\left[\mathrm{HAsc}^{-}\right]=8.6 \times 10^{-4} \mathrm{M}, \mathrm{CblNO}$ was formed within $100 \mathrm{~min}$ from the start of the reaction. During the next 300 min practically no spectral changes were observed, from which we conclude that $\mathrm{CblNO}$ is stable in solution under the selected conditions (Fig. 1b). However, during the next 400 min the absorbance at $476 \mathrm{~nm}$ decreased to the initial value and the $\mathrm{UV}-\mathrm{Vis}$ spectra clearly showed that $\mathrm{CblNO}_{2}$ was reformed fully (isosbestic points at 335, 373, $490 \mathrm{~nm}$ ) (Fig. 1c, d).

Further studies showed that CblNO was formed faster and remained for longer times in the reaction mixture when higher concentrations of $\mathrm{HAsc}^{-}$were used (compare Fig. 2a, $\mathrm{b}$ and $\mathrm{d}$ ), whereas increasing the nitrite concentration slowed down the conversion of $\mathrm{CblNO}_{2}$ to CblNO (compare Fig. $2 \mathrm{~b}$ and c). In a more detailed series of experiments, the nitrite concentration was varied over a wider concentration range while keeping the ascorbate concentration constant. The results reported in Figure S1 (Supporting Information) show that the initial phase of the reaction indeed slows down significantly on increasing the nitrite concentration. The kinetic data could be fitted best with a zero-order process for the initial changes in absorbance with time, and the slopes of such plots as a function of $\mathrm{CblOH}_{2}$ concentration show typical saturation kinetics (see Figure S1e). From the value of $K=1 \times 10^{5} \mathrm{M}^{-1}$ (see Scheme 2) reported at $25^{\circ} \mathrm{C}$ [17], it can be estimated that the concentration of $\mathrm{CblOH}_{2}$ in solution decreases from $1.95 \times 10^{-6}$ to $4.97 \times 10^{-7} \mathrm{M}$ on increasing the nitrite concentration from $4.3 \times 10^{-4}$ to $1.72 \times 10^{-3} \mathrm{M}$ for the experiments reported in Figure S1. This clearly demonstrates the effect of the nitrite concentration on the rate of formation of CblNO. In the presence of a large excess of nitrite, no reaction was observed at all,
Fig. 1 a Spectral changes observed for the reaction between $\mathrm{CblNO}_{2}\left(8.6 \times 10^{-5} \mathrm{M}\right.$, obtained by mixing $\mathrm{CblOH}_{2}$ and $\left.\mathrm{NO}_{2}{ }^{-},\left[\mathrm{NO}_{2}{ }^{-}\right] /\left[\mathrm{CblOH}_{2}\right]=5\right)$ and $\mathrm{HAsc}^{-}\left(8.6 \times 10^{-4} \mathrm{M}\right)$ at pH 4.3 ( $0.1 \mathrm{M}$ acetate buffer, $25^{\circ} \mathrm{C}$, Ar atmosphere) during the first $100 \mathrm{~min}, \mathbf{b}$ between 100 and $400 \mathrm{~min}$, $\mathbf{c}$ between 400 and 1200 min from the start of the reaction. Spectra were recorded every 1 min. d Plot of absorbance at $476 \mathrm{~nm}$ vs. time
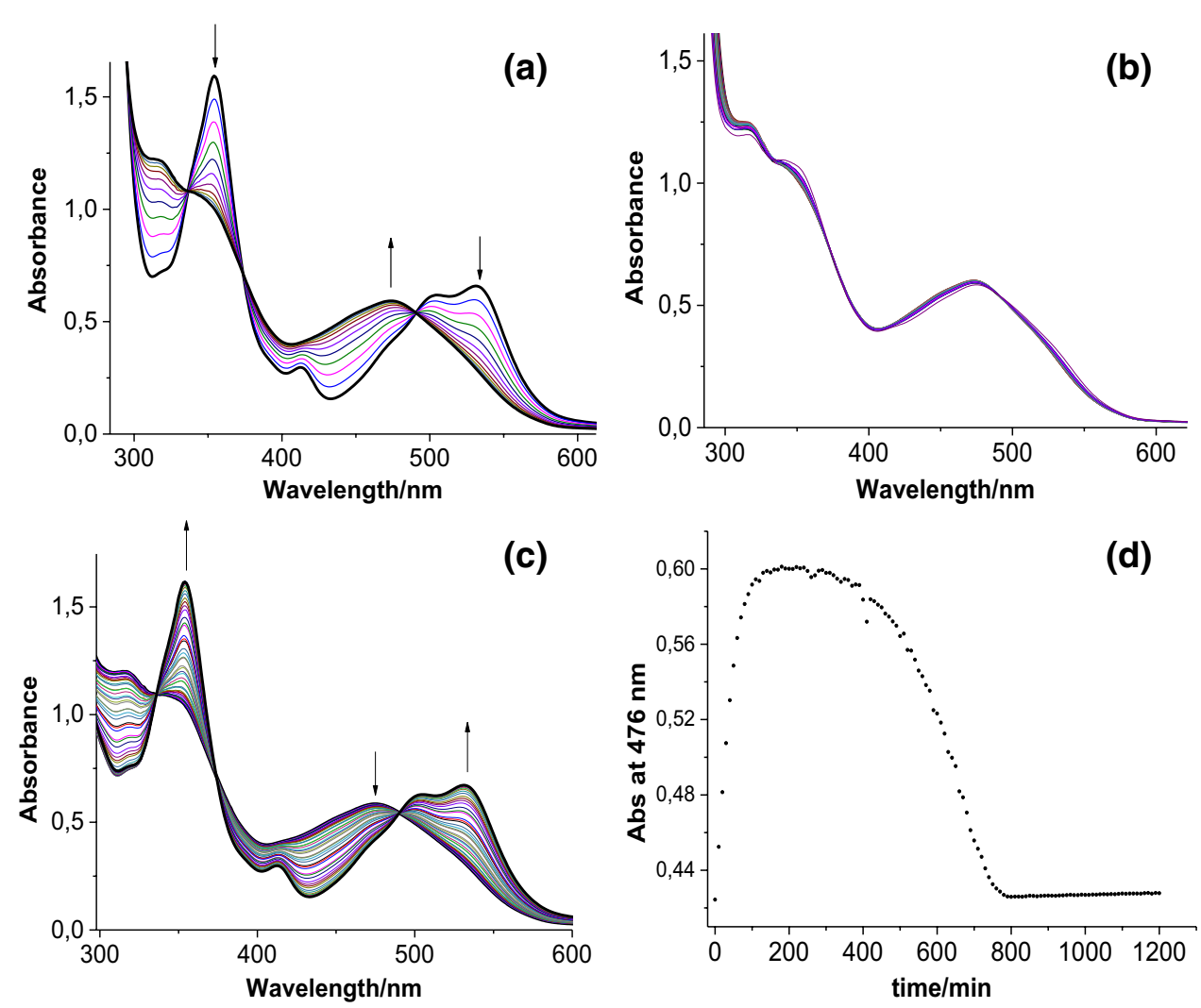
Fig. 2 Plot of absorbance at $476 \mathrm{~nm}$ vs. time for the reaction between $\mathrm{CblNO}_{2}$ $\left(8.6 \times 10^{-5} \mathrm{M}\right.$, obtained by mixing $\mathrm{CblOH}_{2}$ with $\mathrm{NO}_{2}^{-}$) and $\mathrm{HAsc}^{-}$at $\mathrm{pH} 4.3(0.1 \mathrm{M}$ acetate buffer, $25^{\circ} \mathrm{C}$, Ar atmosphere). Concentration ratio for $\left[\mathrm{CblOH}_{2}\right]:\left[\mathrm{NO}_{2}^{-}\right]:\left[\mathrm{HAsc}^{-}\right]: \mathbf{a}$ 1:5:10, b 1:5:20, c 1:10:20 and d 1:10:30
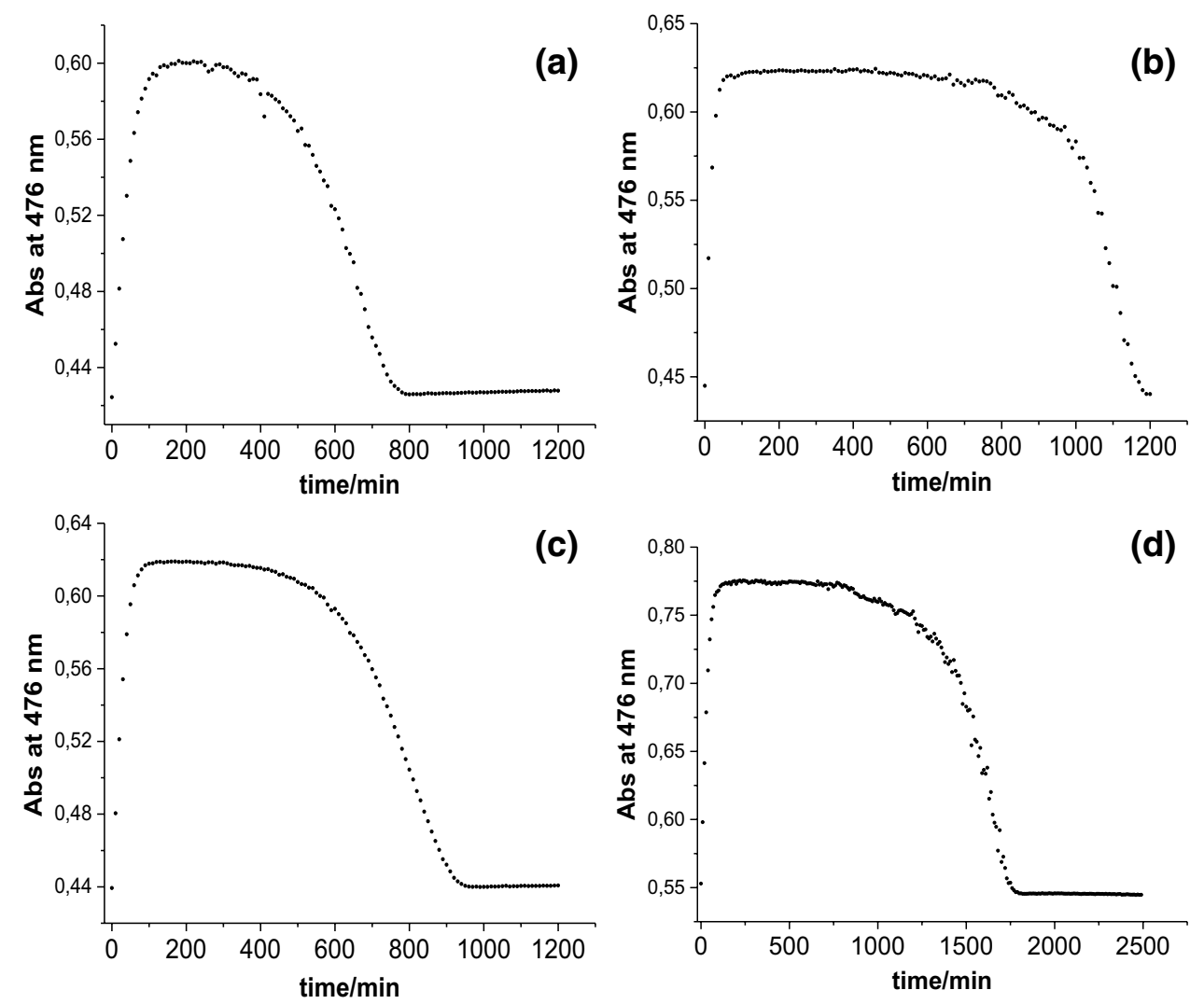

suggesting that nitrite completely suppresses the formation of CblNO.

Additional studies were performed to check whether after almost $20 \mathrm{~h}$ from the start of the reaction, it is possible to reduce the final $\mathrm{CblNO}_{2}$ product by the addition of an extra amount of ascorbic acid. Surprisingly, addition of an extra portion of $\mathrm{HAsc}^{-}$resulted once again in the formation of CblNO as shown in Fig. $3 b$ by the increase in absorbance at $476 \mathrm{~nm}$ from 1100 to $1400 \mathrm{~min}$.

A blank experiment was performed in the absence of cobalamin in which solutions of nitrite and $\mathrm{HAsc}^{-}$were mixed under exactly the same conditions as we used in the experiments with cobalamin. The absorbance maximum at $262 \mathrm{~nm}$ which comes from HAsc ${ }^{-}$decreases with time to reach the pre-reaction value after $20 \mathrm{~h}$ from the start of the reaction (Figure S2, Supporting Information). We ascribe these findings to slow side reactions between ascorbic acid and nitrite, and/or slow diffusion of oxygen into the sealed cuvettes over longer periods of time (see further discussion).

In addition, we could show that by changing the sequence of mixing the reagents this resulted in totally different spectral changes. On mixing first $\mathrm{CblOH}_{2}$ with $\mathrm{HAsc}^{-}$(before addition of nitrite), $\mathrm{CblOH}_{2}$ was fully reduced to $\mathrm{Cbl(II)}$ as shown in Fig. 4a. Subsequent addition of nitrite led to
Fig. 3 a Plot of absorbance at $476 \mathrm{~nm}$ vs. time for the reaction between $\mathrm{CblNO}_{2}$ and $\mathrm{HAsc}^{-}$. b Plot of absorbance at $476 \mathrm{~nm}$ vs. time for the reaction between $\mathrm{CblNO}_{2}$ and $\mathrm{HAsc}^{-}$with the addition of extra $\mathrm{HAsc}^{-}$after $1100 \mathrm{~min}$ from the start of the reaction
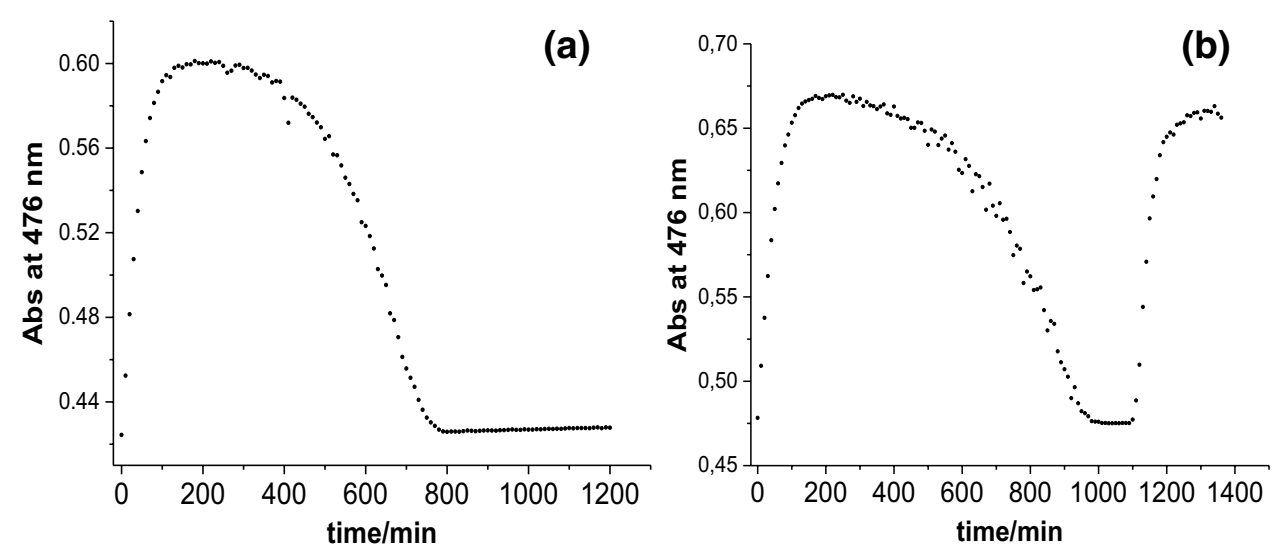
Fig. 4 Spectral changes observed for the reaction between $\mathrm{CblOH}_{2}\left(8.6 \times 10^{-5}\right.$ M) and $\mathrm{HAsc}^{-}\left(8.6 \times 10^{-4}\right.$ $\mathrm{M})$ at $\mathrm{pH} 4.3(0.1 \mathrm{M}$ acetate buffer, $25^{\circ} \mathrm{C}$, Ar atmosphere: a), and for the reaction of $\mathrm{Cbl}$ (II) obtained in a with $\mathrm{NO}_{2}{ }^{-}\left(4.3 \times 10^{-4} \mathrm{M} ; \mathbf{b}, \mathbf{c}\right.$ and d) between 0 and $60 \mathrm{~min}(\mathbf{b})$, between 60 and $600 \mathrm{~min}(\mathrm{c})$ and between 600 and $1200 \mathrm{~min}$ from the start of the reaction (d). In a and $\mathbf{b}$ spectra are recorded every $1 \mathrm{~min}$, whereas in $\mathbf{c}$ and $\mathbf{d}$ every $30 \mathrm{~min}$
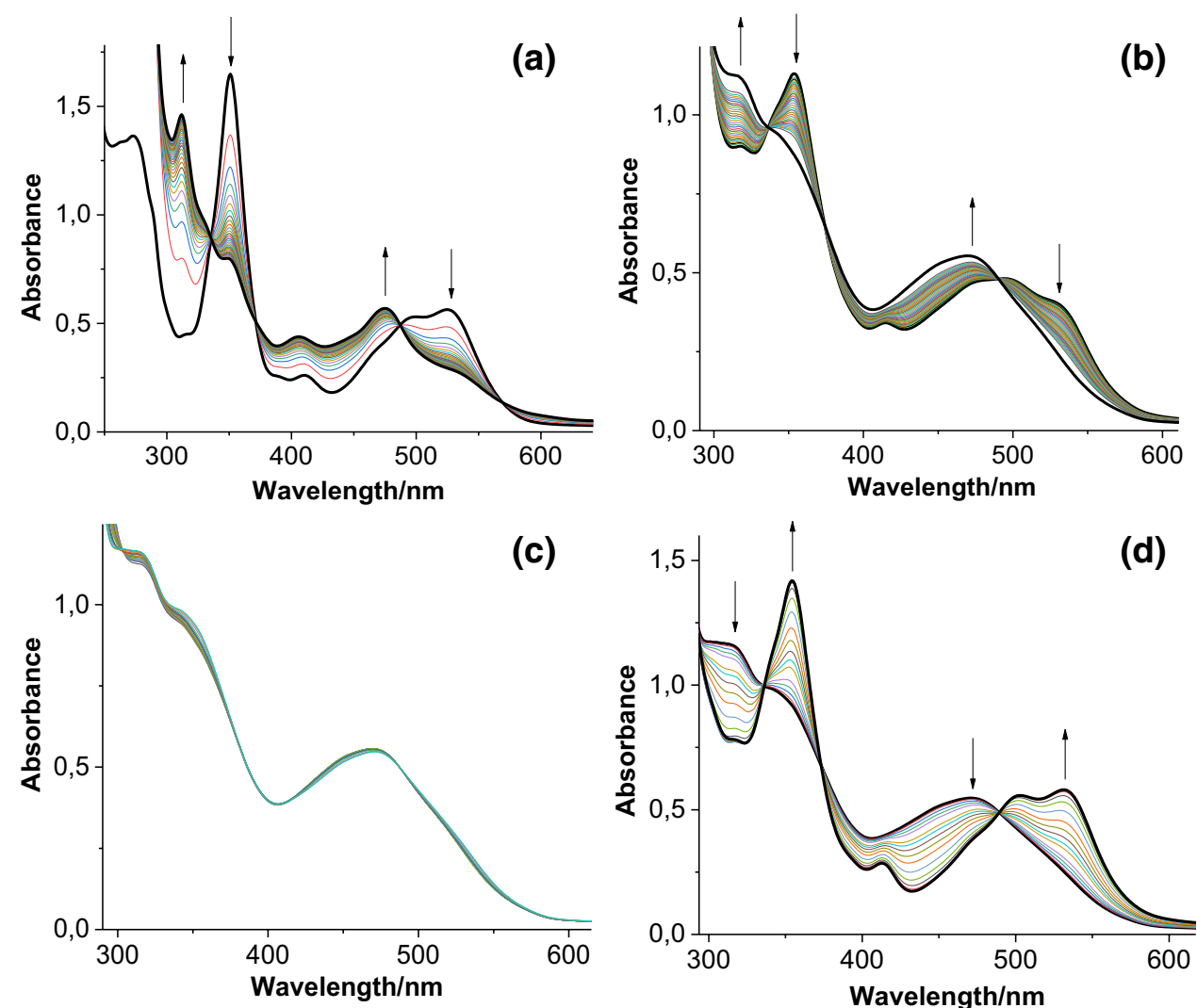

the rapid formation of $\mathrm{CblNO}_{2}$ and not CblNO, i.e. Cbl(II) is oxidized to $\mathrm{CblOH}_{2}$ which reacts rapidly with nitrite to form $\mathrm{CblNO}_{2}$ followed by its reduction to CblNO (Fig. 4b). The CblNO complex remains stable for some time (Fig. 4c) before it slowly converts back to $\mathrm{CblNO}_{2}$ due to the depletion of ascorbate (Fig. 4d).

We also used $\mathrm{Fe}^{\mathrm{II}}($ EDTA) as a very efficient trap for the intermediate formation of $\mathrm{NO}[6,24]$. On mixing typical concentrations of nitrite and ascorbate under Ar atmosphere and allowing them to react for $2 \mathrm{~h}$, the addition of $\mathrm{Fe}^{\mathrm{II}}$ (edta) immediately resulted in the formation of $\mathrm{Fe}$ (edta)NO as shown in Figure S3 (Supporting Information). This is clear evidence for the intermediate formation of NO during the reduction of nitrite by ascorbate under the selected conditions of this study.

The results reported above show that it is indeed possible to observe the formation of CblNO under milder reducing conditions with ascorbic acid at $\mathrm{pH}<5$. In terms of the biological relevance of these findings, we repeated a series of measurements where the $\mathrm{pH}$ was systematically decreased from 7.2 to 5.0 , to see where the changeover from $\mathrm{Cbl}(\mathrm{II})$ to $\mathrm{CblNO}$ as reaction product occurs. In these experiments a typical concentration ratio of $\left[\mathrm{CblOH}_{2}\right]:\left[\mathrm{NO}_{2}^{-}\right]:\left[\mathrm{HAsc}^{-}\right]=1: 5: 10$ was selected as done in Fig. 2. On decreasing the $\mathrm{pH}$ the reaction product changed from only Cbl(II) (pH 7.2, Figure S4, Supporting
Information) to a mixture of $\mathrm{Cbl}(\mathrm{II})$ and CblNO (pH 5.5, Figure S5, Supporting Information), to only CblNO (pH 5.0, Figure S6, Supporting Information). It follows that as we go to milder reducing conditions by lowering the $\mathrm{pH}$, only $\mathrm{Cbl}(\mathrm{NO})$ is formed at $\mathrm{pH} \leq 5.0$, which must be related to the $\mathrm{pH}$ dependence of the redox potential for the two-electron ascorbic acid/dehydroascorbate transformation. According to the Pourbaix diagram for this transformation [18], the redox potential of $\mathrm{H}_{2} \mathrm{Asc}$ at $\mathrm{pH} 0$ is $+0.4 \mathrm{~V}$, of $\mathrm{H}_{2} \mathrm{Asc} /$ $\mathrm{HAsc}^{-}$at $\mathrm{pH} 4.1\left(\mathrm{p} K_{\mathrm{a} 1}\right)$ is $+0.16 \mathrm{~V}$, for $\mathrm{HAsc}^{-}$at $\mathrm{pH} 7.0$ $(8.0)$ is $+0.07(+0.04 \mathrm{~V})$, and for $\mathrm{HAsc}^{-} / \mathrm{Asc}^{2-}$ at $\mathrm{pH} 11.3$ $\left(\mathrm{p} K_{\mathrm{a} 2}\right)$ is $-0.15 \mathrm{~V}$. These data clearly show the large change in redox potential to a significantly stronger reducing agent on increasing the $\mathrm{pH}$ of the solution.

The challenge now will be to find a biologically relevant reducing agent that under mild reaction conditions will reduce $\mathrm{CblNO}_{2}$ to $\mathrm{CblNO}$ at $\mathrm{pH}$ 7.4.

\section{Mechanistic interpretation}

The results of this study have clearly demonstrated that it is possible to obtain stable solutions of CblNO in the presence of a reducing agent starting from $\mathrm{CblNO}_{2}$ under wellselected reaction conditions. The remaining question is how can we account for the different reaction steps observed? 
Our initial idea was that coordinated nitrite can be reduced by ascorbic acid to form the nitroxyl complex CblNO, since this is what the observed spectral changes tell us, thus a direct reaction from $\mathrm{CblNO}_{2}$ to CblNO. However, in these experiments performed at a $\mathrm{pH}<5$ we noticed that the conversion of $\mathrm{CblNO}_{2}$ to CblNO slowed down on increasing the nitrite concentration. In the presence of a large excess of nitrite, no reaction was observed at all. Thus, nitrite suppresses the formation of CblNO, from which we can conclude that ascorbic acid cannot reduce coordinated nitrite. This means that the remaining low concentration of $\mathrm{CblOH}_{2}$ in solution is reduced by the added $\mathrm{HAsc}^{-}$as found in our earlier report [17] and presented in reactions (1) and (2), where DHAsc represents dehydroascorbate.

$$
\begin{aligned}
& \mathrm{CblOH}_{2}+\mathrm{HAsc}^{-} \rightarrow \mathrm{Cbl}(\mathrm{II})+\mathrm{Asc}^{--} \\
& \mathrm{CblOH}_{2}+\mathrm{Asc}^{--} \rightarrow \mathrm{Cbl}(\mathrm{II})+\mathrm{DHAsc}
\end{aligned}
$$

In a subsequent reaction, $\mathrm{Cbl}(\mathrm{II})$ can be oxidized by nitrite to form $\mathrm{CblOH}_{2}$ and $\mathrm{NO}$.

$$
\begin{aligned}
& \mathrm{Cbl}(\mathrm{II})+\mathrm{NO}_{2}^{-} \rightarrow \mathrm{CblOH}_{2}+\mathrm{NO} \\
& \mathrm{Cbl}(\mathrm{II})+\mathrm{NO} \rightarrow \mathrm{CblNO}
\end{aligned}
$$

The $\mathrm{CblOH}_{2}$ formed in reaction (3) is immediately reduced by $\mathrm{HAsc}^{-}$in reactions (1) and (2) and the nitroxyl product is formed in the very fast radical coupling of $\mathrm{Cbl}(\mathrm{II})$ and $\mathrm{NO}$ ( $k=7.4 \times 10^{8} \mathrm{M}^{-1} \mathrm{~s}^{-1}$ [6]), reaction (4). Thus, reactions (1) to (4) account for the observation that CblNO was formed faster and remained for longer times in the reaction mixture when higher concentrations of $\mathrm{HAsc}^{-}$were used, whereas increasing nitrite concentration slowed down the conversion of $\mathrm{CblNO}_{2}$ to CblNO. At the point where ascorbic acid is depleted, CblNO can react with excess $\mathrm{NO}$ to yield $\mathrm{CblOH}_{2}$ and $\mathrm{N}_{2} \mathrm{O}$, similar to that found for the reaction between free $\mathrm{HNO}$ and $\mathrm{NO}$ to form $\mathrm{NO}_{2}{ }^{-}$and $\mathrm{N}_{2} \mathrm{O}$ [25]. Subsequently, $\mathrm{CblOH}_{2}$ is converted to $\mathrm{CblNO}_{2}$, the final reaction product in the presence of excess nitrite.

There are some side reactions (5) and (6) that can contribute to the formation of $\mathrm{NO}$ on a longer timescale and add to the redox cycling that causes the overall decomposition of ascorbic acid to DHAsc and the reformation of $\mathrm{CblNO}_{2}$. These reactions have been known for almost 60 years [26].

$$
\begin{aligned}
& \mathrm{NO}_{2}^{-}+\mathrm{HAsc}^{-\cdot} \rightarrow \mathrm{NO}+\mathrm{Asc}^{--} \\
& \mathrm{NO}_{2}^{-}+\mathrm{Asc}^{--} \rightarrow \mathrm{NO}+\text { DHAsc }
\end{aligned}
$$

In this case, the produced $\mathrm{NO}$ will react rapidly with $\mathrm{Cbl}(\mathrm{II})$ to form $\mathrm{CblNO}$ in reaction (4).

In addition, traces of oxygen can oxidize $\mathrm{NO}$ to $\mathrm{NO}_{2}$ and reform nitrite according to reactions (7)-(9).

$$
\begin{aligned}
& 2 \mathrm{NO}+\mathrm{O}_{2} \rightarrow 2 \mathrm{NO}_{2} \\
& \mathrm{NO}+\mathrm{NO}_{2} \rightarrow \mathrm{N}_{2} \mathrm{O}_{3}
\end{aligned}
$$

$\mathrm{N}_{2} \mathrm{O}_{3}+\mathrm{H}_{2} \mathrm{O} \rightarrow 2 \mathrm{HONO} \rightleftarrows 2 \mathrm{H}^{+}+2 \mathrm{NO}_{2}^{-}$

Reactions (5)-(9) can account for the reformation of nitrite and $\mathrm{CblNO}_{2}$, as well as the overall depletion of ascorbic acid from the solution over longer reaction times.

Traces of oxygen can also oxidize Cbl(II) to form $\mathrm{CblOH}_{2}$, which in turn will be reduced by $\mathrm{HAsc}^{-}$back to Cbl(II) [27-29], by which more ascorbic acid will be used. But at the same time, oxygen will be reduced to form superoxide, peroxide and $\mathrm{OH}$, which are stronger oxidants and can account for more redox cycling to occur during which ascorbic acid will be depleted, reactions (10)-(12). Finally, CblNO can also react with dioxygen to form $\mathrm{CblNO}_{2}$ and $\mathrm{CblOH}_{2}$ in a complex process involving $\mathrm{OH}$ and $\mathrm{NO}_{2}$ intermediates [15].

$$
\begin{aligned}
& \mathrm{Cbl}(\mathrm{II})+\mathrm{O}_{2} \rightarrow \mathrm{CblOH}_{2}+\mathrm{O}_{2}^{-} \\
& \mathrm{Cbl}(\mathrm{II})+\mathrm{O}_{2}^{-} \rightarrow \mathrm{CblOH}_{2}+\mathrm{O}_{2}^{2-} \\
& \mathrm{O}_{2}^{2-}+\mathrm{H}^{+} \rightleftarrows \mathrm{HO}_{2}^{-}+\mathrm{H}^{+} \rightleftarrows \mathrm{H}_{2} \mathrm{O}_{2} \rightarrow 2 \mathrm{OH}^{\circ}
\end{aligned}
$$

The overall reaction sequence for the redox cycling of $\mathrm{CblNO}_{2}, \mathrm{CblNO}$ and $\mathrm{CblOH}_{2}$ in the presence of ascorbate is presented in Scheme 3. The main redox cycling components are marked in red and blue, whereas the oxidation of ascorbate in green. Complications caused by traces of oxygen that could not be avoided over very long reaction times are not included in the scheme for clarity reasons, but are given in reactions (7)-(12).

The suggested reaction sequence in Scheme 3 is based on a one-electron reduction process by which nitrite is reduced to NO by ascorbate. From the recent literature $[30,31]$ it is known that free $\mathrm{NO}$ can be reduced by ascorbic acid to form $\mathrm{HNO}$, which in turn can react with $\mathrm{CblOH}_{2}$ to form CblNO. Brasch and coworkers [32] demonstrated that using Angeli's salt $\left(\mathrm{HN}_{2} \mathrm{O}_{3}{ }^{-}\right)$as source of $\mathrm{HNO}$, the formation of CblNO

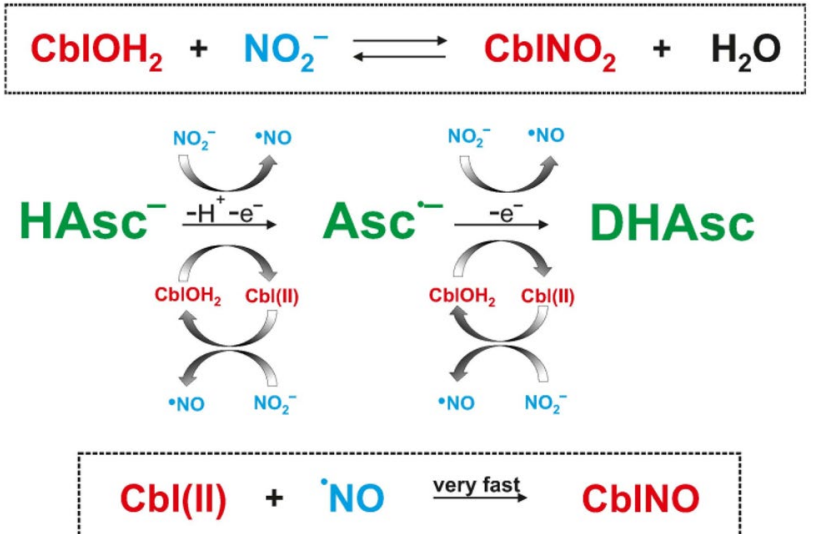

Scheme 3 Overall reaction sequence for the redox cycling of $\mathrm{CblNO}_{2}, \mathrm{CblNO}$ and $\mathrm{CblOH}_{2}$ in the presence of ascorbate 
can occur at $\mathrm{pH}>10.8$, where the rate-determining step is the release of HNO by Angeli's salt, such that no mechanistic details about the mechanism of the reaction between $\mathrm{CblOH}_{2} / \mathrm{CblOH}$ and $\mathrm{HNO} / \mathrm{NO}^{-}$could be revealed. At present, it is questionable whether further reduction of $\mathrm{NO}$ to $\mathrm{HNO}$ and a direct reaction of $\mathrm{CblOH}_{2}$ with $\mathrm{HNO}$ to form CblNO can account for the results presented in this study.

All in all, our goal to find suitable reaction conditions to produce CblNO from $\mathrm{CblNO}_{2}$ in the presence of a reducing agent over a long period of time was successful and has added to the overall understanding of the complex reaction system.

\section{Conclusions}

The reaction of $\mathrm{CblNO}_{2}$, one of the naturally occurring forms of cobalamin, with ascorbate has been studied by UV-Vis spectroscopy. The present study provides mechanistic information on this reaction at $\mathrm{pH}<5$. Under this condition, the only product of the reaction is CblNO. However, for the reduction of $\mathrm{CblNO}_{2}$ by ascorbate, no direct evidence for the reduction of coordinated nitrite could be found. On the contrary, we showed that excess of nitrite suppressed the formation of CblNO, from which we can conclude that ascorbic acid/ascorbate cannot reduce coordinated nitrite. We suggest that the studied system is not just a simple reaction, but a rather complex chemical process. During the reaction of ascorbic acid with nitrocobalamin, the first products formed are the reduced form of Vitamin $\mathrm{B}_{12}(\mathrm{Cbl}(\mathrm{II}))$ and nitric oxide (NO) that subsequently react rapidly to form CblNO. Our results show that the studied reactions are extremely oxygen sensitive due to the reverse oxidation of both $\mathrm{Cbl}$ (II) and $\mathrm{CblNO}$ to $\mathrm{CblOH}_{2}$ and $\mathrm{CblNO}_{2}$, respectively.

Acknowledgements The authors gratefully acknowledge financial support from the National Science Center in Poland (Grant no. DEC-2016/21/N/ST4/00178).

Open Access This article is distributed under the terms of the Creative Commons Attribution 4.0 International License (http://creativeco mmons.org/licenses/by/4.0/), which permits unrestricted use, distribution, and reproduction in any medium, provided you give appropriate credit to the original author(s) and the source, provide a link to the Creative Commons license, and indicate if changes were made.

\section{References}

1. Hassanin HA, Hannibal L, Jacobsen DW, Brown KL, Marques HM, Brasch NE (2009) Dalton Trans. https://doi.org/10.1039/ b810895a
2. Anes JM, Beck RA, Brink JJ, Goldberg RJ (1994) J Chromatogr B Biomed Sci Appl 660:180-185

3. Smith EL, Fantes KH, Ball S, Waller JG, Emery WB, Anslow WK, Walker AD (1952) Biochem J 52:389-395

4. Padovani D, Banerjee R (2006) Biochemistry 45:9300-9306

5. Wolak M, Stochel G, Hamza M, van Eldik R (2000) Inorg Chem 39:2018-2019

6. Wolak M, Zahl A, Schneppensieper T, Stochel G, van Eldik R (2001) J Am Chem Soc 123:9780-9791

7. Zheng D, Yan L, Birke RL (2002) Inorg Chem 41:2548-2555

8. Brouwer M, Chamulitrat W, Ferruzzi G, Sauls D, Weinberg J (1996) Blood 88:1857-1864

9. Wheatley C (2006) Med Hypotheses 67:124-142

10. Shafirovich V, Lymar SV (2002) Proc Natl Acad Sci USA 99:7340-7345

11. Hannibal L, Smith CA, Jacobsen DW, Brasch NE (2007) Angew Chem 119:5232-5235

12. Wolak M, Stochel G, van Eldik R (2006) Inorg Chem 45:1367-1379

13. Suarez-Moreira E, Hannibal L, Smith CA, Chavez RA, Jacobsen DW, Brasch NE (2006) Dalton Trans. https://doi.org/10.1039/ b610158e

14. Trogler WC, Marzilli LG (1974) Inorg Chem 13:1008-1010

15. Subedi H, Brasch NE (2013) Inorg Chem 52:11608-11617

16. Walker DT, Dassanayake RS, Garcia KA, Mukherjee R, Brasch NE (2013) Eur J Inorg Chem. https://doi.org/10.1002/ejic.20130 0254

17. Polaczek J, Orzeł Ł, Stochel G, van Eldik R (2015) J Biol Inorg Chem 20:1069-1078

18. Katafias A, Impert O, Kita P, Fenska J, Koter S, KaczmarekKedziera A, Rozycki H, Bajek A, Uzarska M, van Eldik R (2014) Eur J Inorg Chem 2014:2529-2535

19. Bänsch B, van Eldik R, Martinez P (1992) Inorg Chim Acta 201:75-82

20. Martinez P, Zuluaga J, Kraft J, van Eldik R (1988) Inorg Chim Acta 146:9-12

21. Martinez P, Zuluaga J, Noheda P, van Eldik R (1992) Inorg Chim Acta 195:249-253

22. Martinez P, Zuluaga J, Uribe D, van Eldik R (1987) Inorg Chim Acta 136:11-16

23. Wanat A, van Eldik R, Stochel G (1998) J Chem Soc, Dalton Trans. https://doi.org/10.1039/A802821D

24. Schneppensieper T, Wanat A, Stochel G, van Eldik R (2002) Inorg Chem 41:2565-2573

25. Marchenko AV, Vedernikov AN, Dye DF, Pink M, Zaleski JM, Caulton KG (2004) Inorg Chem 43:351-360

26. Bunton CA, Dahn H, Loewe L (1959) Nature 183:163-165

27. Beaven GH, Johnson EA (1955) Nature 176:1264-1265

28. Das PK, Hill HAO, Pratt JM, Williams RJP (1968) J Chem Soc A Inorg Phys Theor, pp 1261-1264

29. Lexa D, Saveant JM (1976) J Am Chem Soc 98:2652-2658

30. Suarez SA, Neuman NI, Munoz M, Alvarez L, Bikiel DE, Brondino CD, Ivanovic-Burmazovic I, Miljkovic JL, Filipovic MR, Marti MA, Doctorovich F (2015) J Am Chem Soc 137:4720-4727

31. Hamer M, Suarez SA, Neuman NI, Alvarez L, Munoz M, Marti MA, Doctorovich F (2015) Inorg Chem 54:9342-9350

32. Subedi H, Hassanin HA, Brasch NE (2014) Inorg Chem 53:1570-1577 